\title{
JOURNAL.RU
}

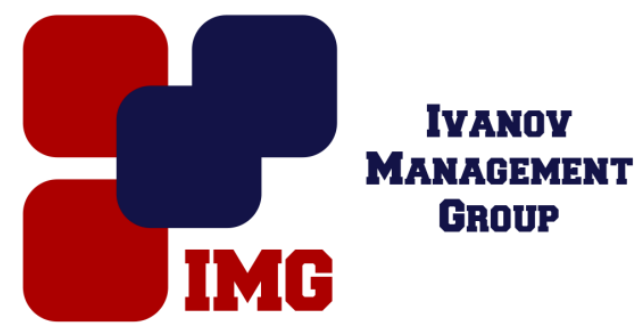

Боброва Е.А., Иванова А.В.

Байкальский государственный университет Иркутск, Россия

doi: 10.18411/lj-30-06-2017-36

idsp 000001:1j-30-06-2017-36

\section{Анималистические метафоры в экономических текстах современного английского языка}

\section{Аннотация}

Данная статья обращается к проблеме исследования метафоризации и метафоры с точки зрения современного когнитивно-ориентированного подхода к исследованию языковых единиц. Метод концептуальных метафор Дж. Лакоффа и М. Джонсона лежит в основе данного анализа метафоризации и его особенностей. Он осуществляется на примере исследования анималистических метафор, которые играют особую роль в деловом дискурсе. В статье приводятся примеры анималистических метафор из современных деловых текстов английского языка, выявляются основные причины широкого использования метафор животного мира в статьях о бизнесе и деловой среде.

Ключевые слова: концептуальная метафора, концептуальная система, деловой дискурс, метафоризация, концепт, когнитивная лингвистика, прикладная лингвистика

Концептуальная метафора прочно укрепились в работах современных ученых-лингвистов как привлекательный объект исследований. Связь процесса метафоризации с познавательными процессами уже не требует доказательств. Современные исследования по метафоре обычно затрагивают особенности метафоризации в разных дискурсах, различные концептуальные составляющие метафор, пространственные основы метафоризации и другие аспекты.Познание окружающего мира с помощью знакомых сущностей, закрепленных в 
концептуальной системе и в языке, и составляют суть концептуальной метафоризации. Как отмечают исследователи-лингвисты Дж. Лакофф, М. Джонсон человек мыслит метафорично. Объясняя более сложные процессы через привычные и знакомые, люди неосознанно прибегают к метафорам[4 ]. В своих работах исследователи-лингвисты анализируют механизмы метафоризации, подчеркивая ее тесную связь с концептами из пространственной сферы, доступными для восприятия объектами физического мира [2 ].

В данной статье акцент делается преимущественно на метафорах животного мира в английском деловом дискурсе, анализируется наиболее распространенные и популярные концептуальные метафоры: их этимология и семантика, а также делаются выводы о значимости концептуальных метафор в деловом английском языке.

Э. Джендрих, анализируя сферу применения метафор в современном английском языке, отмечает, что роль метафоры глубоко изучена в теоретическом аспекте, нонедостаточно исследована в прикладной лингвистике. Автор делает подробный анализ особенностей метафор в деловом дискурсе, предлагает свою классификацию, выделяя смысловые группы различных метафорических выражений. Перечень наиболее распространенных концептуальных метафор, выделенный Э. Джендрих, даёт возможность определить наиболее популярные и семантически емкие метафоры животного мира (animalmetaphors) [3, 129].

Среди наиболее употребляемых отмечаются следующие метафоры:

bearmarket (медвежий рынок, рынок медведей)используется в финансовой сфере для обозначения фондового рынка, который имеет тенденцию к снижению курса, т.е. понижающую тенденцию ;bullmarket(бычий рынок, рынок быков) - также употребляемся в финансовом секторе, и означает рынок, на котором наблюдается тенденция к повышению курсов;cashcow(денежная корова, дойная корова)- данный термин пришел в бизнес-язык из менеджмента. Используемый в Бостонской матрице, он означает хорошо известный на рынке товар, который приносит стабильную и высокую прибыль. EconomicTigers (экономические тигры) - экономический термин, использующийся для обозначения стран, переживающих период неожиданного и быстрого роста. Они сравниваются с тиграми, потому что экономика стран развивается стремительно, совершая большие скачки словно тигр. fatcat (толстый кот) - понятие экономического сектора. Синонимы данного понятия - капиталист, богач, денежный мешок, важная птица. Толстый кот используется как символ 
богатства, особых привилегий, достатка.gazellecompany (компания-газель) экономическая метафора, используемая для обозначения молодых и энергичных, словно газель, компаний, которые недавно вышли на рынок, но стремительно растут и развиваются, loanshark (акулий заем) - метафора используется в банковском секторе для определения ростовщиков, заемщиков, дающих кредиты и займы под большие, «грабительские» проценты, в разы превышающие сумму займа. Такие займы кусаются как акулы и могут быть смертельно опасны для заемщиков. sharkrepellent(отпугиватель акул) - экономическая метафора, имеющая значение мер, принимаемых в компании для защиты от компаний, которые хотят ее поглотить. Здесь крупные компании, желающие поглотить, присоединить, другую компанию сравниваются с акулами, а меры по защите компании с отравой, отпугивателем акул. Необходимо отметить, что использование метафор, содержащих в себе слово «акула» (shark), придает контексту оттенок опасности, что достаточно правдоподобно отражает многие бизнес-понятия. snailmail(улиточная почта) - данная метафора не имеет узкой специфики, но активно применяется в бизнес-лексике, означая обычную почту. Обычная почта, в противовес экспресс-почте, курьерской доставке и т.д., сравнивается с улиткой, акцентируя внимание на медлительности такой почты.swansong (лебединая песня) - широко используемая метафора, применяемая также и в бизнес-английском языке.Употребляется она как синоним шедевра, вершины творчества или иного яркого, значимого для человека поступка, совершенного им в конце своей профессиональной карьеры [3].

Иногда метафоризация охватывает не только отдельные фразы, выражения, отражающие те или иные процессы и аспекты деловой деятельности, но и является основой целого текста. Метафоризация на уровне текста представляет интересный пример концептуальной метафоризации, когда многочисленные отдельные метафорические выражения образуют единство образа целой бизнес-сферы, как например в статье «Whenegoscollide» («Столкновение самомнений»), опубликованной в газете The European и приведенной в учебном пособии «New Insightinto Business»[1, 177]. Автор статьи рассматривает происходящие в деловом мире процессы поглощения компаний через многочисленные аналогии с животным миром.

Анализировать бизнес-процессы гораздо проще, если проводится связь с уже известными и понятными предметами. Так автор статьи сравнивает поведение руководителей фирм с непримиримым поведением 
приматов «...theparallelsbetweenthebehaviourofcorporateexecutivesandthatofgreatape s...»(«...параллели между поведением руководителей компаний и приматами...»). Действительно, часто руководители компаний действует не совсем разумно: они не хотят идти на открытый контакт с противоположной стороной, усложняя переговоры.

Другое сравнение двух противоборствующих руководителей фирм (как представителей компаний) «...these two great beasts of the jungle (the CEO sof the corporations)...» («...эти два гигантских диких зверя в джунглях (топ-менеджеры корпораций)...») приводится автором через сопоставление высшего управляющего звена двух разных компаний с гигантскими дикими животными, а бизнес-среда сопоставляется джунглям. Две противоборствующие стороны, две огромные корпорации, не желающие идти на уступки и обладающие большой экономической силой, сравнением с двумя гигантскими зверьми, воюющими за территорию или ресурсы, упрощают понимание состояния этих компаний. Бизнес-среда, как джунгли, находится под влиянием силы (экономической силы) крупных корпораций. Сравнение бизнес-среды с джунглями обусловлено схожестью этих понятий: «дикие», враждебные условия, превосходство силы, сильных лидеров и т.д.

Похожий смысловой оттенок несет и следующее высказывание в статье «...with a power-hungry alpha male at the to pofeach company...» («...с голодными до власти альфа-самцами на вершине каждой компании...»), каждая компания в лице топ-менеджеров борется за власть на рынке, долю своей продукции и за влияние отсюда и целесообразное сравнение.

Таким образом, проведя анализ существующих в английском деловом языке концептуальных метафор животного мира и изучив лингвистическую практику на основе статьи из СМИ, можно сделать следующий вывод. Концептуальные метафоры, в частности метафоры животного мира, помогают отразить сложные многоплановые процессы, происходящие в деловой среде. Такие концептуальные признаки анималистических метафор, как агрессивность, стихийность, непримиримость, стремление к доминированию и лидерству, борьба за территории и ресурсы, беспощадность, отражают суть бизнеспроцессов емко и точно, помогая наблюдателю или участнику деловой среды, правильно оценить ситуацию и принять верные решения. Таким образом, в подобном лингвистическом анализе актуализируется роль концептуальной метафоры как объекта прикладной лингвистики, выводы которой помогут в решении практических задач. 
1. TullisG., Trappe T. Newinsightintobusiness.Учебноепособие. / G. Tullis, T. Trappe // Longman, 2007. - C.177.

2. Боброва Е.А. Пространственная основа метафоризации концепта LOVE на примере современной англоязычной песенной лирики[Текст] / Е.А. Боброва //Сборник статей Международной научно-практической конференции“Интеллектуальный и научный потенциал XXI века"(г. Волгоград, 23.05.2017). -Уфа: МЦИИ ОМЕГА САЙНС, 2017.c. $25-27$

3. Дженрих Э. Метафора в деловой коммуникации / Э. Дженрих // Труды СанктПетербургского института культуры. - 2016. - №214, С. 117 - 133.

4. Лакофф Дж., Джонсон М. Метафоры, которыми мы живем / Дж. Лакофф, М. Джонсон // Теория метафоры. - 1990. -С. $387-415$. 